УДК 342.9

DOI https://doi.org/10.32844/2618-1258.2019.5-2.25

КРИЛОВ Д.В.

\title{
ДОЗВІЛЬНІ ПРОЦЕДУРИ В ДІЯЛЬНОСТІ ДЕРЖАВНОЇ ПОДАТКОВОЇ СЛУЖБИ УКРАЇНИ
}

\begin{abstract}
Метою статті $\epsilon$ визначення поняття та різновидів дозвільних процедур у роботі Державної податкової служби України. У статті, спираючись на наукові погляди вчених, проводиться аналіз змісту схожих за семантикою та значенням термінів: «дозвільні процедури (провадження)» та «дозвільна система». Розкривається поняття, значення, специфіка та види дозвільних процедур у діяльності Державної податкової служби України. З'ясовано, що дозвільні процедури за своєю природою $є$ унікальною сукупністю операцій адміністративного характеру, адже вони ніяким чином не дублюються в роботі інших органів влади та загалом є предметом виняткової компетенції Державної податкової служби. Доведено, що поняття «ліцензія» і «дозвіл» за своїм змістом є ідентичними і представляють собою спеціальний дозвіл держави, що надає право на здійснення певного виду діяльності у разі дотримання певних вимог, передбачених законодавством. Визначено, що у галузі податкової діяльності термін «дозвіл», а також похідна від нього категорія дозвільної процедури належного висвітлення на цей час не знайшли. Так, ані у нормативно-правових актах, ані на сторінках наукової літератури немає єдиного підходу як до тлумачення дозвільних процедур загалом, так і до визначення останніх у сфері діяльності Державної податкової служби України. Зроблено висновок, що зміст дозвільних процедур у діяльності Державної податкової служби України - це визначені законодавством, послідовно упорядковані дії підрозділів Державної податкової служби України, пов'язані із виданням особливого виду дозволів, ліцензій на провадження діяльності суб'єктами господарювання з виробництва спирту, алкогольних напоїв, тютюнових виробів та пального; з оптової торгівлі спиртом, оптової та роздрібної торгівлі алкогольними напоями, тютюновими виробами, пальним, зберігання пального, а також призупинення та анулювання таких ліцензій.
\end{abstract}

Ключові слова: дозвільна система, дозвільні процедури, Державна податкова служба України.

The purpose of the article is to define the concept and varieties of permitting procedures in the work of the State Tax Service of Ukraine. The content of the terms similar to semantics and the meaning of the terms "permitting procedures (proceedings)" and "permitting systems" are analyzed. The concept, meaning, specifics and types of permitting procedures in the activity of the State Tax Service of Ukraine are revealed. It has been found that permitting procedures are, by their nature, a unique set of administrative operations, since they are in no way duplicated in the work of other authorities and are, in general, a product of the exclusive competence of the State Tax Service. It is proved that the terms "license" and "permit" are identical in their content and represent a special permission of the state, which gives the right to carry out a certain type of activity, subject to certain requirements stipulated by law. It has been determined that in the field of tax activity, the term "permit" and its derivative category of the permit procedure have not been found to date. Thus, neither in the normative legal acts, nor on the pages of scientific literature, there is a single approach both to the interpretation of permitting procedures in general and to the definition of the latter in the sphere of activity of the State Tax Service of Ukraine. It is emphasized that permitting procedures are by their nature a unique set of operations of an administrative nature, since they are in no way duplicated in the work of other authorities, and are generally a product of the exclusive competence of the State ного права)

(С КРИЛОВ Д.В. - доктор економічних наук, докторант (Науково-дослідний інститут публіч- 
Tax Service. It is concluded that the content of the permitting procedures in the activity of the State Tax Service of Ukraine is defined by the legislation, sequentially ordered actions of units of the State Tax Service of Ukraine are related to the issuance of a special type of permits, licenses for conducting activities of economic entities for the production of alcohol, alcoholic beverages, tobacco and fuel; wholesale of alcohol, wholesale and retail sale of alcoholic beverages, tobacco, fuel, fuel storage, and suspension and revocation of these licenses.

Key words: permit system, permit procedures, State Tax Service of Ukraine.

Вступ. У всій багатоманітній структурі адміністративних процедур, які наявні сьогодні в діяльності податкових органів нашої держави, чільне місце займають процедури дозвільного характеру. Варто відмітити, що останні притаманні різним органам державної влади, але в рамках роботи ДПС вони набувають особливого інституційного обрамлення як інструменти забезпечення національної податкової політики. Цей фактор зумовлює необхідність окремого аналізу сутності та найбільш характерних аспектів дозвільних процедур, передбачених у діяльності Державної податкової служби України.

Стан дослідження. Наукову основу дослідження складають роботи авторів, які розглядали загальні особливості, сутність та специфіку дозвільної діяльності в роботі державних органів, а саме: Т.П. Мінки, В.А. Гуменюка, М.М. Бурбики, А.В. Солонара, К.Д. Янішевського Л.В. Карабут, В.І. Ткаченка, О.В. Кузьменко, Ю.А. Хатанюка та інших. Проте питання значення цих процедур у діяльності Державної податкової служби України належним чином не розглядалось.

Постановка завдання. Метою статті є визначення поняття та різновидів дозвільних процедур у роботі Державної податкової служби України.

Результати дослідження. У сучасній словниковій літературі термін «дозвіл» тлумачиться як згода, що дає право на здійснення чого-небудь, документ, який посвідчує певне право [1]. У правовій площині визначення терміну «дозвіл» найбільше сконцентровано у нормативно-правовому матеріалі, зокрема, в законодавчих та підзаконних актах як актуальних, так і тих, що нині не діють. Так, вказане поняття має такі визначення:

- дозвіл - документ установленого зразка, виданий центральним органом виконавчої влади у сфері охорони культурної спадщини, що дає право на проведення археологічних розвідок, розкопок на території пам'ятки, охоронюваній археологічній території, в зонах охорони, історичних ареалах населених місць, а також на дослідження решток життєдіяльності людини, що містяться під земною поверхнею та водою (Закон України «Про охорону археологічної спадщини» від 18.03.2004 №1626-IV);

- дозвіл - документ, оформлений у встановленому порядку, що регулює доступ експлуатанта до конкретного ринку авіаційних перевезень та робіт і пов'язаний з наданням йому певних комерційних прав (Наказ Міністерства транспорту України «Про затвердження Положення про порядок видачі дозволів, що регулюють доступ експлуатантів до ринку авіаційних перевезень та робіт» від 07.10.1999 №487);

- дозвіл - документ установленої форми, виданий розповсюджувачу зовнішньої реклами на підставі рішення виконавчого органу сільської, селищної, міської ради, який дає право на розміщення зовнішньої реклами на певний строк та у певному місці (Постанова Кабінету Міністрів України «Про затвердження Типових правил розміщення зовнішньої реклами» від 29.12.2003 №2067) $[2 ; 3 ; 4 ; 5]$.

Узагальнюючи представлену вище інформацію, зазначимо, що термін «дозвіл» - це надання згоди на щось, зокрема, на провадження певної діяльності. В адміністративно-правовій площині дозвіл - це юридичний акт держави, який надає певне право. У такій формі зміст цього терміну досить часто переплітається із змістом поняття «ліцензія». В законах зазвичай терміни «ліцензія» і «дозвіл» ідуть синхронно (паралельно), термін «дозвіл» вживається з поясненим в дужках «ліцензія», або навпаки. Основані вимоги, що пред'являються до обох понять в законах, механізм видачі і припинення їх ідентичні, тобто законодавець дає зрозуміти, що ці поняття тотожні за суттю і за змістом. Непорозуміння викликають фактичні відносини. Тут держава вимагає для здійснення одних видів господарської діяльності отримання дозволу, для здійснення інших - ліцензії, для третіх - i дозволів і ліцензії. Поняття ліцензії тлумачиться як дозвіл на ведення будь-якої діяльності (ліцензія на ввезення, вивіз будь-якого товару) [6, с. 85; 7, с. 97]. Таким чином, ці два поняття за своїм змістом $є$ ідентичними і представляють собою спеціальний дозвіл 
держави, що надає право на здійснення певного виду діяльності у разі дотримання певних вимог, передбачених законодавством. Те й інше поняття $є$ компонентами одного дозвільного режиму, який являє собою легальну можливість особи, як юридичної, так і фізичної, через подання до відповідного органу заяви про дозвіл здійснити певні визначені дії (зайнятися фармацевтичною діяльністю, придбати зброю та інше) [8, с. 24].

У галузі податкової діяльності термін «дозвіл», а також похідна від нього категорія дозвільної процедури належного висвітлення на цей час не знайшли. Так, ані у нормативно-правових актах, ані на сторінках наукової літератури немає єдиного підходу як до тлумачення дозвільних процедур загалом, так і до визначення останніх у сфері діяльності Державної податкової служби України.

Пояснюється це тим, що у сьогоденній науці адміністративного права та державного управління виділяють одразу декілька рівнозначних у деяких моментах за своєю сутністю понять, що характеризують дозвільний напрям роботи органів влади, у тому числі ДПС, а саме довільна система та дозвільна процедура, або ж провадження.

Найчастіше в доктринальних та законодавчих джерелах діяльність із надання дозволів називають саме дозвільною системою. Наприклад, у Законі України «Про дозвільну систему у сфері господарської діяльності» від 06.09.2005 №2806-IV визначено, що дозвільна система у сфері господарської діяльності - це сукупність урегульованих законодавством відносин, які виникають між дозвільними органами, адміністраторами та суб'єктами господарювання у зв'язку з видачею документів дозвільного характеру, переоформленням, анулюванням документів дозвільного характеру [9]. Відповідно до положень Постанови Кабінету Міністрів України «Про затвердження Положення про дозвільну систему» від 12.10.1992 № 576 дозвільна система - це особливий порядок виготовлення, придбання, зберігання, перевезення, обліку і використання спеціально визначених предметів, матеріалів і речовин, а також відкриття та функціонування окремих підприємств, майстерень і лабораторій з метою охорони інтересів держави та безпеки громадян [10].

На думку Т.П. Мінки та В.А. Гуменюка, дозвільна система - це об'єктивно існуюча і наділена певними якісними характеристиками сукупність правових відносин, які виникають між фізичними та юридичними особами, з одного боку, а також суб'єктами державного управління та іншими контрагентами - 3 іншого, спрямована на реалізацію суб'єктивних прав із приводу здійснення дозволених законом дій щодо таких предметів, створінь, процесів у природі чи суспільстві, неврегульоване використання або функціонування яких може завдати шкоди інтересам людини, суспільства і держави [11, с. 2-3]. М.М. Бурбика, А.В. Солонар та К.Д. Янішевська пропонують розглядати категорію дозвільної системи у широкому та вузькому змісті. Так, у широкому розумінні, на думку авторів, дозвільна система - це сукупність правил, які передбачають отримання дозволу на здійснення певної діяльності та регламентують контроль за нею. Дозвільна система у вузькому розумінні - це особливий порядок здійснення визначених дій над законодавчо закріпленим переліком об'єктів, проведення операцій, які вимагають спеціального дозволу компетентних органів. Дозвільна система передбачає отримання таких дозвільних документів: спеціальний дозвіл; ліцензія; сертифікат [12, с. 145].

Не меншим колом визначень характеризується поняття дозвільної процедури (провадження). Наприклад, Л.В. Карабут, В.І. Ткаченко, О.В. Кузьменко, О.М. Бокій вважають, що дозвільна процедура - це регламентована адміністративно-процесуальними нормами діяльність органів публічної адміністрації, під час якої вирішуються питання щодо забезпечення реалізації прав фізичних та юридичних осіб на виконання певних дій або зайняття певними видами діяльності шляхом надання їм відповідного дозволу [13, с. $147 ; 14$, с. 127]. Ю.А. Хатанюк, Ю.С. Кіцул, Г.О. Лиско вказують на те, що під дозвільною процедурою варто розуміти врегульовану правом сукупність суспільних відносин суб'єктів адміністративної влади з фізичними та юридичними особами, що виникають у зв’язку з видачею дозволів на заняття певними видами діяльності та подальшим наглядом за дотриманням правил і умов здійснення дозволеної діяльності До особливостей дозвільного провадження належать такі: загальнодержавний, підзаконний та виконавчо-розпорядчий характер; здійснюється особливою групою державних органів, на які покладено обов'язки з практичної реалізації функцій держави; здебільшого має попереджувальний (профілактичний) характер; його сутність становлять встановлені нормативно-правовими актами правила діяльності, дії або поведінка громадян, юридичних осіб, державних органів і їх посадових осіб та контроль і нагляд за їх виконанням [15].

Отже, аналіз категорій «дозвільна система» та «дозвільна процедура» («провадження)» показав їх близький зміст, адже в обох випадках йдеться про діяльність із надання спеціально- 
го державного документу, який може мати форму як безпосередньо дозволу, так і сертифікату, ліцензії, спеціального дозволу тощо. Подібний документ посвідчує та надає особливе право на зайняття якоюсь діяльністю, придбання товарів певного виду, проведення конкретних робіт тощо. При цьому варто зауважити про розмежування понять «дозвільна система» та «дозвільна процедура» («провадження»). Так, з огляду на наукові думки та наявні законодавчі положення дозвільна система - це сукупна назва діяльності держави із оформлення та надання документів дозвільного характеру в певній сфері, наприклад, дозвільна система в сфері господарської діяльності. Тобто це характеристика напряму роботи, яка включає в себе різний адміністративний інструментарій.

Дозвільна процедура, або провадження, є вужчим за змістом поняттям, ніж дозвільна система, та характеризується сукупністю нормативно-встановлених, послідовних адміністративних операцій конкретного органу державної влади, спрямованих на оформлення та видачу довільного документу (дозволу, ліцензії тощо), який надає виняткове, індивідуальне право на певні дії. При цьому варто зауважити, що дозвільна процедура та дозвільне провадження є цілком ідентичними поняттями, оскільки протилежне на цей час не доведено, а за етимологією слова «провадження» та «процедура»є близькими за значенням. У зв'язку із цим наявна ситуація простого заміщення термінів.

Для характеристики дозвільних процедур у діяльності Державної податкової служби України проаналізуємо їх загальне місце в роботі вказаного органу. Так, відповідно до Положення про Державну податкову службу України на ДПС покладаються повноваження щодо здійснення:

- ліцензування діяльності суб'єктів господарювання з виробництва спирту, алкогольних напоїв та тютюнових виробів, з оптової торгівлі спиртом, оптової та роздрібної торгівлі алкогольними напоями, тютюновими виробами;

- ліцензування діяльності суб’єктів господарювання з виробництва пального, 3 оптової, роздрібної торгівлі та зберігання пального і контроль за таким виробництвом [16].

Порядок здійснення дозвільних процедур із видачі ліцензій відповідно до покладених на ДПС повноважень регламентовано спеціальною нормативно-правовою базою, зокрема, Законом України «Про державне регулювання виробництва і обігу спирту етилового, коньячного і плодового, алкогольних напоїв, тютюнових виробів та пального» від 19.12.1995 №481/95-ВР. Зазначений нормативний акт визначає основні засади державної політики щодо регулювання виробництва, експорту, імпорту, оптової і роздрібної торгівлі спиртом етиловим, коньячним і плодовим та зерновим дистилятом, спиртом етиловим ректифікованим виноградним, спиртом етиловим ректифікованим плодовим, дистилятом виноградним спиртовим, спиртом-сирцем плодовим, біоетанолом, алкогольними напоями, тютюновими виробами та пальним, забезпечення їх високої якості та захисту здоров'я громадян, а також посилення боротьби з незаконним виробництвом та обігом алкогольних напоїв, тютюнових виробів та пального на території України [17].

Так, Державна податкова служба України видає, призупиняє, анулює ліцензії на виробництво спирту етилового, коньячного і плодового та зернового дистиляту, спирту етилового ректифікованого виноградного, спирту етилового ректифікованого плодового, дистиляту виноградного спиртового, спирту-сирцю плодового, біоетанолу, алкогольних напоїв та тютюнових виробів і пального [17].

Існують певні особливості ліцензування в кожному окремому випадку. Так, ліцензії на виробництво спирту етилового, коньячного і плодового та зернового дистиляту, спирту етилового ректифікованого виноградного, спирту етилового ректифікованого плодового, дистиляту виноградного спиртового, спирту-сирцю плодового, біоетанолу видаються суб'єктам господарювання (у тому числі іноземним суб' єктам господарювання, які діють через своє зареєстроване постійне представництво) - юридичним особам, а на виробництво алкогольних напоїв та тютюнових виробів - усім суб'єктам господарювання (у тому числі іноземним суб'єктам господарювання, які діють через своє зареєстроване постійне представництво).

Ліцензії на виробництво тютюнових виробів видаються лише суб'єктам господарювання (у тому числі іноземним суб'єктам господарювання, які діють через своє зареєстроване постійне представництво), які мають повний технологічний цикл виробництва тютюнових виробів, включаючи виготовлення тютюнової суміші, сигаретні цехи. Своєю чергою ліцензії на право виробництва пального видаються із додатковим наданням законодавчо визначених документів [17].

Таким чином, проаналізовані положення законодавства показали, що дозвільні процедури в роботі органів Державної податкової служби України займають незначну частку функціоналу останньої. Ці процедури пов’язані із виданням особливих видів дозволів (ліцензій - право 
суб’єкта господарювання на провадження виду господарської діяльності або частини виду господарської діяльності, що підлягає ліцензуванню) на зайняття виробництвом або торгівлею спирту, алкогольних напоїв та тютюнових виробів, а також пального [17]. В своїй сукупності дозвільні процедури формують окремий напрям роботи ДПС, пов'язаний із регулюванням та забезпеченням державної політики в секторі обігу спиртовмістких речовин, тютюнових виробів та пального.

Окрім того, подібні дозвільні процедури за своєю природою $є$ унікальною сукупністю операцій адміністративного характеру, адже вони ніяким чином не дублюються в роботі інших органів влади та загалом є предметом виняткової компетенції Державної податкової служби.

Висновки. Спираючись на представлену інформацію, теоретичні погляди теоретиків права, а також дійсні законодавчі положення національного нормативно-правового сектору, нами було побудовано власне бачення змісту дозвільних процедур в діяльності Державної податкової служби України, - це визначені законодавством, послідовно упорядковані дії підрозділів Державної податкової служби України, пов'язані із виданням особливого виду дозволів, ліцензій на провадження діяльності суб'єктами господарювання з виробництва спирту, алкогольних напоїв, тютюнових виробів та пального; з оптової торгівлі спиртом, оптової та роздрібної торгівлі алкогольними напоями, тютюновими виробами, пальним, зберігання пального, а також призупиненням та анулюванням цих ліцензій.

\section{Список використаних джерел:}

1. Білодід І.К. Словник української мови: в 11 томах. Том 2, 1971. Стор. 347.

2. Про охорону археологічної спадщини: закон від 18.03.2004 №1626-IV. Вiдомості Верховної Ради України. 2004. № 26. Ст. 361.

3. Про затвердження Положення про порядок видачі дозволів, що регулюють доступ експлуатантів до ринку авіаційних перевезень та робіт: наказ від 07.10.1999 № 487. Офіuійний вісник Украӥни. 1999. № 45. Ст. 2255.

4. Про затвердження Типових правил розміщення зовнішньої реклами: постанова від 29.12.2003 № 2067 // Урядовий кур’єр. 2004. № 11.

5. Про затвердження Порядку проведення у 2005 році аукціонів 3 продажу спеціальних дозволів (ліцензій) на користування надрами: постанова від 30.08.2005 № 828. Офіиійний вісник Украӥни. 2005. № 35. Ст. 2120.

6. Юридичні терміни. Тлумачний словник/За ред. В.Г. Гончаренка. Київ : Либідь, 2003.320 с.

7. Словник іншомовних слів: 2300 слів та технологічних словосполучень / Укладач Л.О. Пустовіт та ін. Київ : Довіра, 2000. С. 1018.

8. Шпомер А.І. Ліцензування господарської діяльності (господарсько-правовий аспект) : дисертація. Київ : Київський національний університет імені Тараса Шевченка. 2006. 233 с.

9. Про дозвільну систему у сфері господарської діяльності: закон від 06.09.2005 № 2806-IV. Відомості Верховної Ради України. 2005. № 48. ст.483.

10. Про затвердження Положення про дозвільну систему: постанова, положення від 12.10.1992 №576. Офіційний веб-портал законодавства України. URL: https://zakon.rada.gov.ua/ laws/show/576-92-п.

11. Мінка Т.П. Адміністративно-правові режими та їх забезпечення органами внутрішніх справ : дисертація. Дніпропетровськ, 2011. 610 с.

12. Бурбика М.М., Солонар А.В., Янішевська К.Д. Адміністративне право України : н авчальний посібник. Суми : Видавничо-виробниче підприємство «Мрія», 2015. 358 с.

13. Бокій О.М. Адміністративно-правовий режим обігу зброї в Україні: дисертація. Київ : Київський національний університет внутрішніх справ. 2010. 260 с.

14. Правові засоби здійснення дозвільної системи органами внутрішніх справ України : практ. посіб у 2-х ч. : Ч. 1 / Л.В. Карабут, В.І. Ткаченко. Луганск : РВВ ЛДУВС, 2007. 384 с.

15. Хатанюк Ю.А., Кіцул Ю.С. Поняття та особливості дозвільного провадження. Науковий вісник Ужгородського національного університету. 2018. С. 20-23.

16. Про затвердження положень про Державну податкову службу України та Державну митну службу України: постанова, положення від 06.03.2019 № 227. Офіційний вісник України. 2019. № 26. Ст. 900.

17. Про державне регулювання виробництва і обігу спирту етилового, коньячного і плодового, алкогольних напоїв, тютюнових виробів та пального: закон від 19.12.1995 № 481/95-ВР. Відомості Верховної Ради України. 1995. № 46. Ст. 345. 